\title{
On Structural Sources of the 1994 Turkish Crisis: a CGE modelling analysis
}

\section{A. Erinç Yeldan}

To cite this article: A. Erinç Yeldan (1998) On Structural Sources of the 1994 Turkish Crisis: a CGE modelling analysis, International Review of Applied Economics, 12:3, 397-414, DOI: 10.1080/02692179800000015

To link to this article: http://dx.doi.org/10.1080/02692179800000015

曲 Published online: 28 Jul 2006.

Submit your article to this journal $\pi$

Џ Article views: 66

Q View related articles ¿

4 Citing articles: 6 View citing articles 


\title{
On Structural Sources of the 1994 Turkish Crisis: a CGE modelling analysis
}

\author{
A. ERINÇ YELDAN
}

\begin{abstract}
This paper investigates the impact of the Turkish public sector imbalances on the evolution of the economic crisis during 1990-93. A computable general equilibrium model is used. The theoretical basis of the model rests upon the structuralist/Keynesian macro foundations. Its distinguishing features entail accommodation of oligopolistic mark-up pricing rules in the industrial sectors, and endogenous solution of capacity utilisation and unemployment levels through Keynesian mechanisms of effective final demand. The results of the model underscore the importance of intra-class relations of income distribution and conflict in the evolution of price movements in the Turkish economy. It is further argued that the sources of the crisis lie in the administrative interventions of the state towards protection of the capitalist and rural incomes, which would otherwise be squeezed out in favour of wage-labour in the early 1990s.
\end{abstract}

\section{Introduction}

Beginning in January 1994, the Turkish economy suffered a major financial crisis which was followed by real contraction. Real Gross Domestic Product (GDP) declined by more than $5 \%$ over the year, with the inflation rate soaring to almost $150 \%$, and the number of unemployed increasing by at least 600000 . Concurrently, the pace of capital accumulation, both public and private, severely contracted, while the trade deficit rose to unprecedented levels. By the end of 1994 , the stock of domestic debt rose to $20 \%$ of GDP, from $2.4 \%$ only four years before. Interest payments on domestic debt emerged as a major category of distribution, squeezing out the non-financial claims on aggregate value added.

By 1995, the GDP recovered and the major thrust of the crisis seemed to have been overcome. However, as of mid-1997 the repercussions of the crisis are still being felt, with annual price inflation running at $85-90 \%$ (the highest in the OECD); the trade deficit reaching US $\$ 20$ billion; and the public sector borrowing requirement (PSBR) at $7 \%$ of the GDP.

The main indicators of this period are summarised in Table 1 . It can easily be seen that the growth performance of the post-1990 Turkish economy was one of mini boom-and-bust cycles. The gross domestic product fluctuated widely with rates of growth recording sharp peaks $(9.3 \%$ in $1990,8.0 \%$ in 1993 and $7.3 \%$ in $1995)$ to be followed by severe contractions in the immediate aftermath $0.9 \%$ in 
$1991,-5.4 \%$ in 1994). The cyclical pattern is observed to be closely related to the 'external gap' (Taylor, 1996, 1994). In general, high growth years were associated with the availability of external finance to cover the current account deficits and expansion of imports. The ongoing import liberalisation led to a faster rise in imports than exports, which by 1990, had already lost their thrust of the 1980s.

The period was also characterised by a rapid deterioration of the fiscal position of the state (Sak et al., 1996; Atiyas, 1995; Boratav et al., 1996; Onder et al., 1993). As Table 1 shows, the major breakdown occurred in the flow of net factor income generated by the state economic enterprise system, and in the rapid rise of the transfer expenditures. The major cause of this phenomenon was the sudden increase in real wage costs, fuelled by political-economy pressures of the civilian elections of 1989 and 1990 . In manufacturing, real wages rose by $18.5 \%$ in 1990 , and by $64.9 \%$ in 1991 . Factor revenues declined by TL 4.6 trillion in real 1987 values over a period of four years from 1988 to 1992 . Even though there had been modest improvements in tax revenues, the surge in transfer expenditures overran such gains. As a ratio of GNP, current transfers rose from $6.1 \%$ in 1991 , to $12.0 \%$ in 1994 . Likewise, the saving generation capacity of the public sector was eroded severely and turned negative after 1992. The aggregate disposable income of the public sector fell by $30 \%$ in real terms between 1988-95, and the public saving-investment gap widened by almost fourfold.

All these developments led to a sharp increase in the public sector borrowing requirement, which increased to $11.7 \%$ of the GNP in 1993, just before the outbreak of the 1994 economic crisis. The state resorted to a massive operation of domestic debt financing by way of new issues of debt instruments and implemented both market and administrative (non-market) mechanisms to attain the necessary resources for financing its fiscal operations. The government debt instruments dominated the financial markets. In 1995, the share of new issues of public securities stood at $90 \%$ of the total; and the share of public assets in the secondary market reached $95 \%$ (Balkan \& Yeldan, 1996).

Under these conditions, the stock of domestic debt grew rapidly to reach $20 \%$ of the GNP by the end of 1995 . The interest payments on domestic debt increased from $2.4 \%$ in 1990 , to $6.2 \%$ of the GNP in 1995 . A critical feature of debt accumulation was its extreme short term maturity. By 1992, the state was already trapped in a Ponzi-style finance of its debt, with net new government borrowings reaching $92 \%$ of the outstanding domestic debt. By 1995, this ratio had accelerated to $132 \%$.

It is generally well-accepted among students of the Turkish economy that the main sources of the crisis can be traced to the culminating pressures of large fiscal deficits on the part of the state. In this paper, I attempt to analyse the basic underlying processes of the crisis from a political economy perspective of class conflict and pressure, along with conflicting interests on income distribution and accumulation. To this end, the paper employs a 'Computable General Equilibrium' (CGE) model. Utilising the CGE apparatus as an 'economics laboratory', I investigate the factors which led to fiscal disequilibrium and finally to the economic crisis, through explicit modelling of the strategic behaviour of antagonistic social classes in the factor and product markets.

The plan of the paper is as follows: first, I introduce the salient features of the model, and then calibrate it to the Turkish historical path of 1990-93. In Section 
Table 1. Main economic indicators, Turkey

\begin{tabular}{|c|c|c|c|c|c|c|c|}
\hline & 1985 & 1990 & 1991 & 1992 & 1993 & 1994 & 1995 \\
\hline \multicolumn{8}{|l|}{ Annual $\%$ Change } \\
\hline GDP & 4.2 & 9.3 & 0.9 & 5.9 & 8.0 & -5.4 & 7.3 \\
\hline \multicolumn{8}{|l|}{ Consumption } \\
\hline Private & 4.4 & 13.1 & 1.9 & 3.3 & 8.4 & -7.5 & 7.6 \\
\hline Public & 1.7 & 7.9 & 4.5 & 3.8 & 6.2 & -7.6 & 6.7 \\
\hline \multicolumn{8}{|l|}{ Fixed Capital Formation } \\
\hline Private & 7.6 & 19.4 & 0.9 & 4.3 & 34.6 & -22.2 & 14.9 \\
\hline Public & 5.7 & 8.9 & 1.8 & 4.3 & -1.6 & -31.6 & -16.9 \\
\hline Exports & 7.3 & 3.1 & 3.1 & 11.1 & 7.7 & 15.4 & 6.7 \\
\hline Imports & 5.5 & 33.1 & -5.3 & 10.9 & 35.1 & -22.4 & 30.0 \\
\hline \multicolumn{8}{|l|}{ Ratios to GNP (\%) } \\
\hline Public Sector Factor Income & 5.2 & 3.1 & 0.6 & -0.1 & 0.6 & 1.9 & 2.2 \\
\hline Public Sector Current Transfers & -4.9 & -6.5 & -6.1 & -6.7 & -9.2 & -12.0 & -11.4 \\
\hline Public Disposable Income & 14.4 & 13.4 & 11.8 & 11.4 & 9.6 & 8.9 & 8.2 \\
\hline Budget Deficit & -2.2 & -3.1 & -5.3 & -4.3 & -6.8 & -3.7 & -4.0 \\
\hline PSBR & 3.6 & 7.4 & 10.3 & 10.6 & 11.7 & 8.2 & 6.6 \\
\hline \multicolumn{8}{|l|}{ Interest Payments on: } \\
\hline Domestic Debt & 0.7 & 2.4 & 2.7 & 2.8 & 4.6 & 6.1 & 6.2 \\
\hline Foreign Debt & 1.2 & 1.1 & 1.1 & 0.9 & 1.2 & 1.6 & 1.3 \\
\hline Stock of Domestic Debt & 4.5 & 6.2 & 6.8 & 10.0 & 12.7 & 13.9 & 19.8 \\
\hline Current Account Balance & -1.5 & -1.7 & 0.2 & -0.6 & -3.5 & 2.0 & -1.4 \\
\hline \multicolumn{8}{|l|}{ Prices and Distribution Indicators } \\
\hline Manufacturing Real Wage Rate Index & 64.0 & 100.0 & 164.9 & 147.3 & 150.7 & 104.4 & 90.9 \\
\hline Consumer Prices ( $\%$ Change) & 43.2 & 60.4 & 71.1 & 66.2 & 66.1 & 125.5 & 84.4 \\
\hline Exchange Rate Depreciation ( $\%$ Change) & 40.9 & 22.9 & 59.9 & 65.2 & 59.4 & 171.9 & 54.0 \\
\hline Interest on Gov. Debt Instruments (\%) & 50.6 & 55.0 & 71.0 & 75.0 & 80.3 & 166.2 & 111.8 \\
\hline
\end{tabular}

Sources: SIS Annual Statistics, Undersecretariat of Treasury and Foreign Trade, Main Economic Indicators 
3, I analyse the main socio-economic processes behind this historical path via a series of counter-factual simulations. Section 4 summarises and concludes.

\section{The Computable General Equilibrium Model}

\subsection{The General Structure and Dimensions}

The CGE model employed in this study is based on the recent 1990 input-output table of the Turkish economy published by the State Institute of Statistics (SIS, 1994) and extended by Kose \& Yeldan (1996). It is built around 15 production sectors; six socio-economic classes; a central government; and the foreign sector. The theoretical structure of the model is based on a general equilibrium framework with optimising agents facing endogenous price signals (Dervis et al., 1982), and on the structuralist school (Taylor, 1981, 1991; Gibson \& van Seventer, 1996; Davies \& Rattsø, 1996).

The distinguishing feature of the macro closure utilised in the model is a series of macro adjustments on income distribution, foreign exchange, and forced savings so as to finance a pre-determined level of fiscal expenditures. Within this adjustment process, the aggregate price level and the nominal exchange rate work endogenously to bring equilibrium in the commodity markets. A portion of private savings is claimed by the state as forced savings in order to finance its fiscal deficit, while any insufficiency of the aggregate domestic funds is closed by alignments in the foreign rate of exchange and by foreign transfers.

A major limitation of the model is its restricted capability to account for the generation of financial/rentier incomes based on arbitrage possibilities in the banking and the financial sectors. Evidence suggests that with extensive liberalisation of the financial markets in the late 1980s there has been a shift in the secondary relations of distribution favouring rentiers and the financial centres (see for example, Boratav et al., 1994, 1996; Yeldan, 1995). However, given its micro equilibrium structure, the model focuses exclusively on the real sphere of the domestic economy. In this setting, the so-called profit income of the financial bourgeoisie, as distinguished in the model, is derived from the value added of the commercial and financial services sector by deducting wage payments. Thus, the financial sources of income can only be captured to the extent that they emanate from transactions with the real sectors of the economy.

Private agents and the public sector are distinguished as two different bodies carrying out decisions on savings and the composition of final demand. For both categories, savings are generated via fixed saving propensities out of their respective disposable incomes.

The output of each sector is produced by a single representative firm employing intermediates and primary inputs. Primary inputs consist of (physical) capital and labour. Labour input is further decomposed into two categories: organised wage-labour, and informal/marginal labour. Labour demand decisions are derived from the marginal productivity conditions of profit maximisation. The nominal wage rate of the organised labour is given exogenously, and the organised labour market clears through quantity adjustments on employment. Unemployed 'wage-labour' is pooled with the 'marginal-labour' category where flexible movements of the informal labour wage rate clear the aggregate labour surplus.

In manufacturing, the final product price is determined by a fixed mark-up rate over average variable costs. This specification is designed to reflect 
the oligopolistic market power in the sector. In response to increased wage and intermediate input costs, the producer secures its level of profits via application of the fixed mark-ups, thereby passing increased production costs on to the final consumers, inflating the aggregate price level. This mechanism generates an important source of structural inflation in the manner described by Taylor (1991) and Bourguignon et al., (1991).

Under the mark-up induced pricing behaviour, market supplies of the manufacturing sectors are determined by endogenous movements of the rate of capacity utilisation. The underlying production technology for value added is assumed to be Cobb-Douglas, and that of intermediate input use is regarded as Leontieff. In this manner, denoting the sectoral use of capital, wage-labour, and informal marginal-labour, respectively, by $K_{j}, L_{\mathrm{wj}}$, and $L_{m j}$; the intermediate input aggregate by $V_{i j}$; the Leontieff coefficients by $a_{i j}$; and the capacity utilisation rate by $U_{j}$, output supply in sector- $j$ becomes,

$$
X_{j}^{S}=\min \left[\frac{V_{1 j}}{a_{1 j}}, \frac{V_{2 j}}{a_{2 j}}, \ldots, \frac{V_{n j}}{a_{n j}} ; U_{j} \cdot F\left(K_{j}, L_{W_{j}}, L_{M j}\right)\right]
$$

In this fashion, under the pre-determined price, product market equilibrium is obtained by capacity adjustments, which in turn lead to reduced employment and output supply at the sectoral level.

Private income is generated from value added income, transfers from the central government budget, and exogenous transfers from the rest of the world. The public disposable income consists of income taxes, tariffs on imports, and the production and corporate taxes levied on producers. The public savings rate and the aggregate level of public investment are regarded as exogenous policy instruments. In general, planned public savings fall short of the realised investment expenditures; and the public saving-investment deficit (GSIDEF) is covered through foreign borrowing (FSAV^ER) plus 'forced' transfers from the private savings pool. Price inflation constitutes the major mechanism behind this adjustment, as it opens a wedge between the ex ante expenditure plans and their realisations for the private agents, thereby acting as an implicit tax. This mechanism entails, on the one hand, excess demand disequilibria in the product markets leading to inflationary pressures; and, on the other, leads to real appreciation of the domestic currency through induced inflows of foreign borrowing. Thus, the overall macro-equilibrium of the domestic economy satisfies:

$$
\text { GSIDEF }=\text { HHSAV }- \text { PRINV + FSAV }{ }^{\star} E R
$$

where HHSAV-PRINV is private savings surplus over private investment. This structure captures quite successfully the recent Turkish reality with culminating inflationary pressures; faltering and erratic rates of growth with boom-and-bust cycles of real production; and stagnant exports and an unprecedented current account deficit accompanied by currency appreciation (in purchase-price-parity terms).

This summarises our discussion of the main attributes and distinguishing features of the CGE model. ${ }^{\prime}$ We now turn to applications in the Turkish historical growth path, 1990 through 1993. 


\subsection{Historical Simulations of the Model, 1990-93}

The model tracks the following variables for the period 1990-93: the annual rate of domestic inflation, the exchange rate, gross national product and sectoral production, wages, employment, fiscal balances, foreign trade transactions, and the macro aggregates such as consumption, savings and investment. The values of the historically realised levels of the variables between 1990 and 1993 are to be contrasted below with the model's simulation values in Table 2 .

The three most important prices for our analysis are the overall domestic price level, the foreign rate of exchange (TLUS\$), and the formal labour wage rate. Among these, the first two are solved endogenously by the model, whereas the nominal wage rate is regarded as exogenous. The mark-up rates are also treated exogenously. Given the data of the Istanbul Chamber of Industry (1995) they are adjusted upwards by $10 \%$ between 1990 and 1991, and are held at their respective rates for the rest of the period.

The production values track their historical levels closely, and reproduce the value of gross national product both in net factor prices and in producer (market) values. The observed discrepancies in the nominal value of GNP are recorded at the rate of $2.5 \%$ in 1991 and 1992 ; and at $1.0 \%$ in 1993. Components of expenditures on the national product are listed in the remaining rows of Table 2 , where the model's expenditure structure is found to compare closely with the historical structure.

\section{Evolution of the Crisis and Its Components}

In this section, the 1990-93 simulated growth path will be utilised as a benchmark to investigate the 1994 crisis. Three interrelated issues will be considered: (i) the role of the unprecedented rise in the fiscal deficit on the evolution of the crisis; (ii) the roles of the foreign borrowing strategy of the state on the balance of payments and on the foreign exchange rate; and (iii) the inflationary processes emanating from real wage increases and oligopolistic pricing behaviour in the industrial sectors.

\subsection{Fiscal Balances of the State: experiment E1}

Over this period, the most striking indicator over the public sector balances pertains to the borrowing requirements of the state. As a ratio of GNP, the PSBR increased rapidly from $5.2 \%$ in 1990 to reach $7.0 \%$ in 1991 , and has stabilised at that plateau. Concurrently, the volume of public savings deteriorated severely, and fell from $3.5 \%$ of GNP in 1990 , to $0.4 \%$ in 1991 , and to $-3.5 \%$ in 1993 .

In addition, net factor earnings of the public sector fell from their GNP ratio of $5 \%$ in 1985 , to $3.1 \%$ in 1990 , and to $0.6 \%$ in 1991 . Revenues from corporate taxes also experienced a severe erosion. Their share in the aggregate budgetary revenues is observed to decline from its peak of $15 \%$ in 1986 , to a mere $7 \%$ in 1992. On the other hand, the 1993 value of the current transfers, which has been the major expenditure item in the fiscal accounts, exceeded its 1990 level by $75 \%$ in real terms, amounting to an increase of 8.3-fold in nominal prices.

Had these adverse developments not occurred in the public sector balances, what would the consequences be for the domestic economy? How would the macro balances differ from the realised path? In this first experiment, these 
Table 2. Model validation of selected macro indicators

\begin{tabular}{|c|c|c|c|c|c|c|c|}
\hline & \multirow[b]{2}{*}{1990} & \multicolumn{2}{|c|}{1991} & \multicolumn{2}{|c|}{1992} & \multicolumn{2}{|c|}{1993} \\
\hline & & Model & Historical & Model & Historical & Model & Historical \\
\hline GNP (a) & 395.0 & 649.2 & 634.4 & 1132.6 & 1103.6 & 1977.5 & 1997.3 \\
\hline GDP (factor prices) (a) & 357.1 & 592.6 & 607.9 & 1019.6 & 1052.6 & 1794.9 & 1900.6 \\
\hline Historical/Model GNP & & 0.977 & & 0.974 & & 1.010 & \\
\hline \multicolumn{8}{|l|}{ Composition of GNP (\%) } \\
\hline Public disposable income & 14.4 & 12.5 & 12.8 & 11.6 & 11.8 & 9.8 & 9.7 \\
\hline Public consumption & 10.9 & 12.1 & 12.3 & 12.6 & 12.8 & 12.9 & 12.8 \\
\hline Public savings & 3.4 & 0.4 & 0.4 & -1.0 & -1.0 & -3.1 & -3.1 \\
\hline Public investment & 8.7 & 7.3 & 7.6 & 6.5 & 6.5 & 6.3 & 6.2 \\
\hline Public sav-inv deficit & 5.2 & 6.9 & 7.1 & 7.5 & 7.5 & 9.4 & 9.3 \\
\hline Private disposable income & 85.6 & 87.5 & 87.2 & 89.4 & 88.2 & 90.5 & 90.3 \\
\hline Private consumption & 66.4 & 68.7 & 68.5 & 67.5 & 66.5 & 66.9 & 66.8 \\
\hline Private savings & 19.3 & 18.8 & 18.8 & 22.0 & 21.7 & 23.6 & 23.5 \\
\hline Private investment & 17.3 & 14.9 & 14.8 & 16.1 & 15.8 & 19.3 & 19.3 \\
\hline Foreign deficit & 3.2 & 3.0 & 3.0 & 1.6 & 1.6 & 5.1 & 5.2 \\
\hline Imports (b) & 24.695 & 23.500 & 21.047 & 24.800 & 22.871 & 28.895 & 29.428 \\
\hline Exports (b) & 11.154 & 11.720 & 13.594 & 13.495 & 14.719 & 14.139 & 15.348 \\
\hline Price level (c) & 100 & 163 & 165 & 277 & 282 & 473 & 470 \\
\hline Exchange rate (TLUS\$) & 2630 & 4121 & 4181 & 6867 & 6882 & 10825 & 10985 \\
\hline Wage rate index (d) & 100 & 194 & 194 & 300 & 300 & 511 & 511 \\
\hline Sectoral price indexes: & 100 & & & & & & : \\
\hline Agriculture & 100 & 158 & 151 & 276 & 245 & 473 & 398 \\
\hline Mining & 100 & 162 & 163 & 272 & 262 & 472 & 413 \\
\hline Industry & 100 & 176 & 155 & 257 & 253 & 492 & 395 \\
\hline
\end{tabular}

Notes. ${ }^{a}$ SIS New GNP Series, in current trillion TL. ${ }^{b} 1990$ Billions US $\$^{c}$ Consumer price index ${ }^{d}$ Nominal wage remunerations of insured workers (exogenously given in the model). 


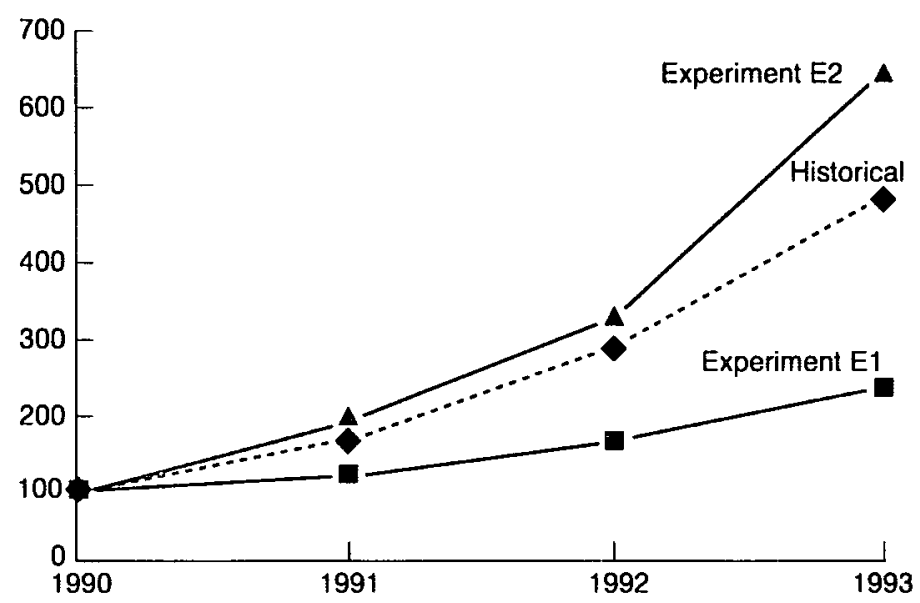

Fig. 1. Domestic inflation rate under experiments $\mathrm{E} 1$ and E2.

questions will be studied. The counter-factual scenario is designed as follows: first, we increase the public savings-GNP ratio to its 1980 s average of $4 \%$, from its realised value of $-1.3 \%$ over 1991-93. We then reduce the annual rate of increase of nominal public consumption expenditures from $81 \%$ to $45 \%{ }^{2}$. Likewise, the rate of growth of current transfers is reduced to $45 \%$ in nominal terms. To compensate for the revenue losses, net factor earnings of the public sector are increased to the 1980 s' level of $3 \%$ of the GNP. Finally, the erosion of the corporate tax revenues is reversed by increasing the corporate tax rate to $15 \%$ (its average over 1983-87), from its level of 5\% of 1990.

The results are given in Table 3. The simulated rate of inflation (CPI) is shown in Fig. 1. Accordingly, under the assumptions of the experiment, the annual rate of price increase is calculated to be $30 \%$ over the $1990-93$ period, down from its historically realised rate of $68 \%$. This result is further complemented by positive developments in production, where the real GNP increases by 3.5\% over its 1993 value; and in exports, where a $2.9 \%$ increase is recorded. Finally, the experimental results reveal an annual increase of $22 \%$ in the public disposable income in real terms, and the public saving-investment gap is reduced by $56.9 \%$.

Is it possible to make such an isolated assessment of fiscal balances of the state, independent of all other historical socio-economic developments of the period? In other words, could the Turkish state have replicated the model's technical results, which were obtained under a set of exogenous assumptions? This question invokes the political economy issues of income distribution and real income generation within the private sector.

Results in Table 3 further suggest that the real income level of industrial capital falls by $8.5 \%$ in 1991 , and by $3.7 \%$ in 1993 , as compared to its historical values. Contraction of the services capital income is even more pronounced with a $13.9 \%$ reduction by 1993 . In a similar vein, rural incomes also suffer a loss of $3.1 \%$; with the urban-workers the only group to become better off. Consequently, under the assumptions of the experiment, while public income improves, private capital incomes erode.

One can underline the experimental results in the following manner: in the Turkish economy, under the conditions of the early 1990s, when real wage costs 
Table 3. Macroeconomic indicators: experiments E1 and E2 (percentage changes over the historical values)

\begin{tabular}{|c|c|c|c|c|c|c|}
\hline & \multicolumn{3}{|c|}{ Experiment E1 } & \multicolumn{3}{|c|}{ Experiment E2 } \\
\hline & 1991 & 1992 & 1993 & 1991 & 1992 & 1993 \\
\hline GNP & 2.2 & 2.8 & 3.5 & -4.2 & -4.4 & -9.6 \\
\hline Foreign deficit & 3.6 & 5.7 & 9.5 & & & \\
\hline Public disposable income & 43.7 & 57.7 & 83.5 & -0.1 & 0.3 & 2.6 \\
\hline Private disposable income & -3.7 & -4.3 & -5.1 & -4.7 & -5.0 & -10.9 \\
\hline \multicolumn{7}{|l|}{ Consumption Expenditures } \\
\hline Public & 15.1 & 8.1 & 6.9 & 0.0 & 0.0 & 0.0 \\
\hline Private & -3.7 & -3.7 & -5.1 & -4.7 & -5.0 & -10.9 \\
\hline \multicolumn{7}{|l|}{ Domestic Savings } \\
\hline Public & 829.2 & 493.8 & 231.8 & -3.7 & 3.2 & 8.0 \\
\hline Private & -3.7 & -4.3 & -5.1 & -4.7 & -5.0 & -10.9 \\
\hline \multicolumn{7}{|l|}{ Investment Expenditures } \\
\hline Public & 30.0 & 40.2 & 30.4 & 0.0 & 0.0 & 0.0 \\
\hline Private & 5.7 & 10.4 & 24.1 & -26.0 & -16.5 & -38.6 \\
\hline Exports & 1.0 & 1.8 & 2.9 & 9.9 & 7.3 & 18.6 \\
\hline Imports & 0.8 & 1.4 & 2.0 & -16.1 & -12.9 & -28.0 \\
\hline \multicolumn{7}{|l|}{ Private Factor Incomes } \\
\hline Rural & -3 & -3.2 & -3.8 & -2.7 & -3.4 & -6.8 \\
\hline Marginal-labour & 1.2 & 2.0 & 3.3 & -5.5 & -4.7 & -11.7 \\
\hline Wage-labour & 7.8 & 8.0 & 7.8 & -4.9 & -3.7 & -9.3 \\
\hline Industrial labour & 7.8 & 10.8 & 15.5 & -10 & -6.9 & -16.5 \\
\hline Services labour & 7.7 & 6.5 & 3.4 & -2.2 & -2.0 & -5.2 \\
\hline Industrial capital & -8.5 & -6.7 & -3.7 & -2.9 & -2.1 & -4.5 \\
\hline Services capital & -13.1 & -13.2 & -13.9 & -5 & -4.6 & -13.2 \\
\hline
\end{tabular}


scored rapid increases and the production and export performance of the domestic economy faltered, the rapid erosion of the fiscal balances of the state served for the protection of the urban-capitalist and rural incomes in real terms. The costs of this 'protection' entailed the rapid surge of the domestic price inflation from its possible annual rate of $35 \%$ to $68 \%$, and the loss of aggregate gross national product by $3.5 \%$, and export revenues by $2.9 \%$. At the micro level, this process meant administration of an extensive scheme of production subsidies and current transfers, and controlling the prices of state enterprises. Consequently, conducive conditions could have been generated for the private capital to 'absorb' the rapid increases in costs of wage-labour.

As extensively discussed in Yeldan (1995), the fiscal deficit of the Turkish state between 1990 and 1993 does not necessarily imply a problem of 'bureaucratic mis-management' in the abstract; but is a reflection of the administrative and socio-economic policies on the part of the public sector, which were deemed necessary to sustain the generation of economic surplus for the private capital. The state has used its taxation-cum-subsidy policies and the prices (losses) of its production enterprises as the strategic instruments of this historical manoeuvre, and financed its fiscal deficits via forced savings by way of price inflation and increased foreign indebtedness.

\subsection{Foreign Borrowing and Short Term Capital Inflows: experiment E2}

Turkey has liberalised its capital account and declared full convertibility of its currency in August 1989. This policy had significant repercussions in the financial economy. For the monetary authority it basically meant the loss of control over the real rate of interest and the foreign exchange rate as instruments of stabilisation policy, as these variables came under the direct scrutiny of the arbitrage opportunities in the international markets (Uygur, 1994; Balkan \& Yeldan, 1996; Boratav et al., 1996).

Beginning in 1990, foreign capital movements were observed to display sensitivity with respect to the differential on the rate of interest and foreign exchange. The foreign capital inflows in 1990 amounted to US\$3 billion. In 1993, the aggregate amount of foreign capital transferred into the domestic economy reached US $\$ 9.3$ billion, or $5.6 \%$ of the GNP.

Thus, in this period the foreign capital inflows served the dual function of covering the public sector deficits as well as expanding the import capacity of the domestic economy. The state was able to finance its deficits through borrowing at high interest rates, which, in turn, stimulated the financial (speculative) capital inflows. Yet the costs of this fragile equilibrium were reflected on the traded sectors as a consequence of currency appreciation and faltering export demand. As a version of this 'Dutch Disease' phenomenon spread, imports expanded rapidly, and the ratio of exports to imports fell to 0.52 in 1993, from its 1989 value of 0.74 .

The purpose of this experiment is to examine the following question: 'What would the inflationary consequences and the macro balances be, had the possibilities of foreign capital inflows been restricted in the 1990s?'. To this end, the experiment imposes zero net foreign borrowing and foreign transfers to the economy throughout the 1991-93 period. All other factors, which were regarded as exogenous under the historical base-simulation-such as the fiscal deficits, real wage increases, etc-are kept intact. The analysis of this experiment is based on the reports in Table 3 above, and Figs 1 and 2 . 


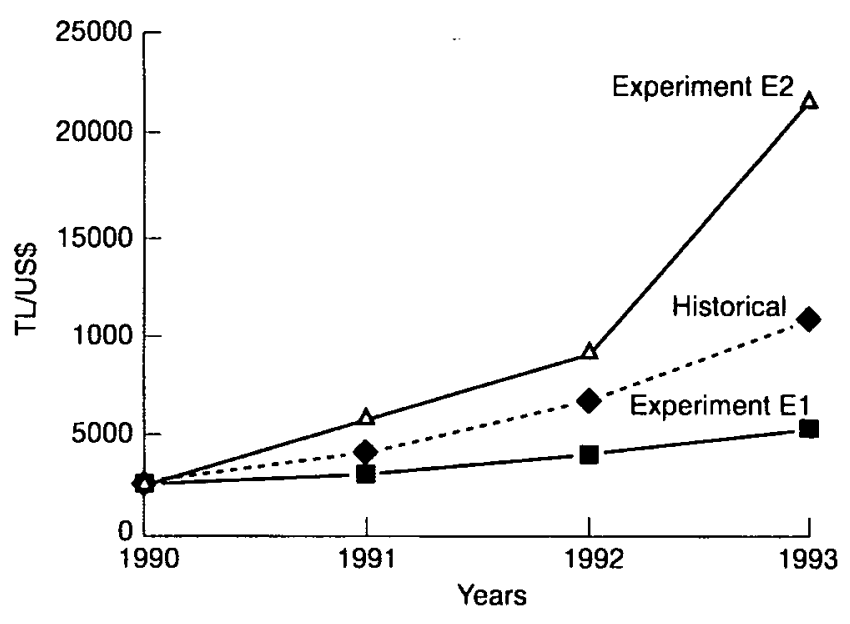

Fig. 2. Exchange rate, experiments E1 and E2.

The elimination of foreign capital transfers into the economy has inflationary consequences, increasing the annual rate of increase of consumer prices to $84 \%$. In the meantime, as compared with the 1993 levels, the gross national product falls by $9.6 \%$; and the private sector real disposable income and consumption fall by $10.9 \%$. Thus, under the assumptions of experiment E2, the domestic economy drifts into real contraction and price inflation.

Results on factor income, as displayed in Table 3, further complement this picture, indicating large losses for the private sector. In comparison with end-of1993 values, industrial-capitalist incomes decline by $4.5 \%$; industrial labour incomes by $16 \%$, and the rural incomes by $6.8 \%$.

Figure 2 portrays the path of the nominal rate of foreign exchange. Elimination of foreign capital inflows naturally leads to depreciation of the currency in order to equilibrate the balance of payments accounts. Accordingly, the equilibrium nominal exchange rate reaches $21816 \mathrm{TL} / \$$ in 1993 , as compared to its realised rate of $10825 \mathrm{TL} / \$$. However, under experiment $\mathrm{E} 1$, reduction of the fiscal deficits results in deflation of the price level and appreciation of the currency.

Not surprisingly, the major consequence of currency appreciation of the post-1989 period was stagnation of the overall export performance, together with the massive expansion of imports. Thus, foreign liberalisation and the consequent capital inflows served to cover the deficits of the public sector on the one hand, and stimulated the consumption propensities of the private sector, on the other. Yet this short-lived invigoration did not lead to a sustainable expansion of real production, and was met by increased imports. This mechanism, which was based on a fragile balance between the rates of domestic interest and the foreign exchange, collapsed by the end of 1993 , leading to financial chaos and to a severe contraction of the real GNP in the months to follow.

\subsection{Wage Costs and the Oligopolistic Market Behaviour: experiments 3 and 4}

In many popular writings, wage costs are regarded as the main source of price inflation in the Turkish economy. However, the existing data are far from providing support for this claim. Observations on the quantitative indicators do not seem to support the hypothesis that the main inflationary dynamics in Turkey 


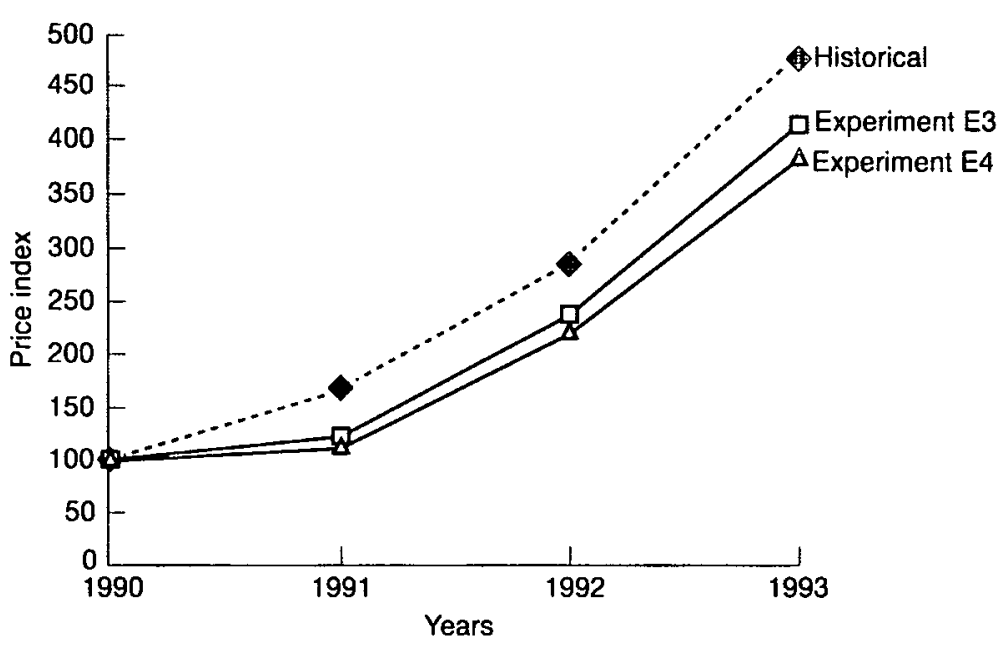

Fig. 3. Wages, oligopolistic pricing and domestic inflation.

are to be found in wage costs. To analyse this hypothesis in a more formal manner, we will study both the cost-push and the demand-creation effects of wage increases in our general equilibrium framework under experiment E3. Under this experiment, real wages are kept constant at their 1990 level, and all other public sector variables are set to their previously assumed levels. However, anticipating the expected cost savings on the public employee wage bill, I treat the aggregate public consumption expenditures item as endogenous along the experiment. With this technical change in the closure rule of the model, aggregate public employment in the public services sector is regarded as a given constant; thereby decreases in the wage costs reduce the public consumption expenditures on a direct basis. ${ }^{3}$

The simulated inflation rate under these assumptions is displayed in Fig. 3. Maintenance of the real wage rate at its 1990 level results in a reduction of the 1993 value of the consumer price index from 473 points, to 409 index points (with the price index set equal to 100 in 1990), lowering the average annual rate of price inflation by 8 percentage points to $60 \%$ over the period $1990-93$.

Here, an important issue is related to the role of the profit margins in setting cost dynamics. In discussions about the 'cost-push' aspects of price inflation, current debates generally focus solely on the wage-costs of labour, ignoring the pressures emanating form the profit/rent recipients. Yet, oligopolistic pricing strategies based on independent mark-ups over average variable costs are observed to be a common feature of price formation in the Turkish manufacturing sectors. Under this mechanism, the economic returns to the capitalist are effectively protected by way of mark-ups, and the increases in costs are directly reflected onto the final consumers via price adjustments.

Such oligopolistic pressures on price dynamics are analysed through the simulation of experiment E4, and are further to be contrasted with the results obtained under E3. Figure 3 discloses that, under the 'competitive' pricing configuration, the implemented cost savings on real wages generate a further reduction of 5 percentage points in the annual rate of inflation, dampening the rate of growth of producer prices to $55 \%$. In other words, experiment $\mathrm{E} 4$ suggests that the mark-up based oligopolistic pricing strategy in the manufacturing sector has contributed as much as 5 percentage points to the overall inflation in the Turkish 


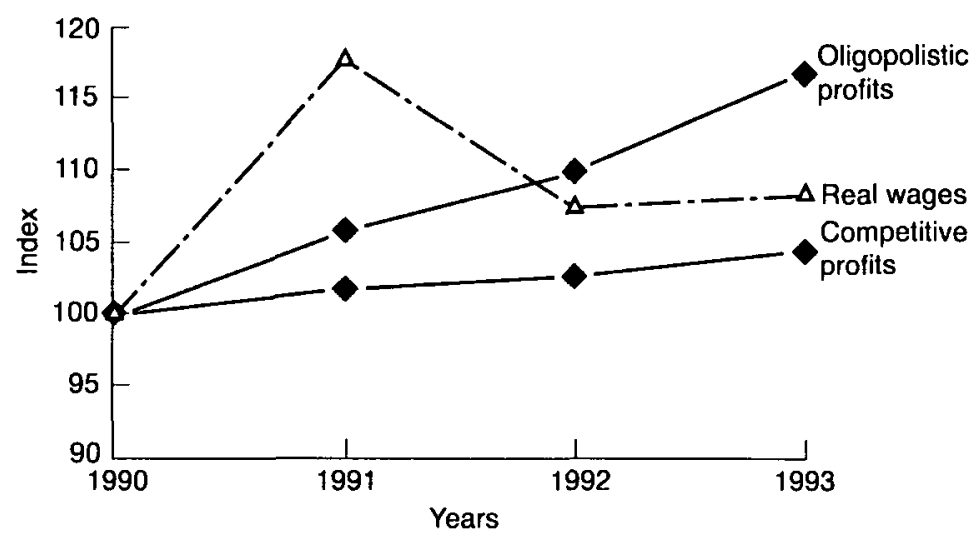

Fig. 4. Wages and oligopolistic profits in the manufacturing industry.

economy. Confronted with rising wage-costs, industrialists could have sustained their profits by inflating the final prices of the products they supply and thus have led to a process I will refer to as 'profit/rent induced inflation'.

This technical analysis is portrayed in Fig. 4, where the evolution of the profit income against the real wage movements is contrasted under the (historical) oligopolistic versus the (hypothetical) competitive pricing environments. The figure plots the historically realised wage rate changes, admitting an increase to the index $(1990=100)$ level of 119 in 1991 , and stabilising at 108.2 in 1993 . The historical simulation path on profits reveals that 'oligopolistic profits' follow the real wage path, maintaining the real rate of return to capital. Per contra, had the capital-owner faced the real wage increases under a competitive configuration, the profit rates would have fallen and the consequent price inflation would have been lower.

This process is displayed at the sectoral level in Table 4. Under the 'historical' column, against the real wage index increases of 108.2, the average manufacturing real profit index reaches 116.2 points. Thus, the model solutions suggest that, under the 'historical' simulation, assuming a value of 1.0 in 1990, the profit/wage ratio increases to 2.291 in 1993 . Under the oligopolistic conditions of E3, elimination of real wage increases leads the aggregate profit index to reach 117.4 points. However, under the competitive setting of experiment E4, one would expect the index of (competitive) profits to be 105.2, and the price index to be pulled down to 376 index points.

The macro consequences of experiments E3 and E4 are displayed in Table 5. One of the most interesting observations of experiment E3 is that elimination of real wage increases brings forth a $0.2 \%$ decline in GNP as compared to its 1993 historical level. Per contra, under the same wage assumptions, but with a competitive pricing environment of $\mathrm{E} 4$, gross national product is observed to increase by $1.0 \%$ over its 1993 value. Hence, a comparison of E3 and E4 suggests that the economic costs of oligopolistic pricing behaviour in Turkish manufacturing are not restricted to profit/rent induced price inflation, but entail real output losses, as well. 
Table 4. Real wages, profits and capacity utilisation in the manufacturing industry, experiments E3 and E4

\begin{tabular}{|c|c|c|c|c|c|c|c|}
\hline & \multirow[b]{2}{*}{1990} & \multicolumn{2}{|c|}{ Historical } & \multicolumn{2}{|c|}{ Experiment E3 } & \multicolumn{2}{|c|}{ Experiment E4 } \\
\hline & & 1991 & 1993 & 1991 & 1993 & 1991 & 1993 \\
\hline Real wage index & 100.0 & 119.0 & 108.2 & 100.0 & 100.0 & 100.0 & 100.0 \\
\hline Average profit rate index & 100.0 & 106.5 & 116.1 & 108.5 & 117.4 & 100.7 & 105.2 \\
\hline Profit/wage ratio (a) & 1.000 & 2.303 & 2.291 & 2.302 & 2.265 & 2.297 & 2.264 \\
\hline Average capacity utilisation rate & 100.0 & 96.5 & 93.3 & 94.1 & 92.3 & 100.0 & 100.0 \\
\hline
\end{tabular}

${ }^{a}$ Ratio of aggregate profits to aggregate wage costs. 
Table 5. Macroeconomic indicators: experiments E3 and E4 (percentage changes over the historical solution values)

\begin{tabular}{|c|c|c|c|c|c|c|}
\hline & \multicolumn{3}{|c|}{ Experiment E3 } & \multicolumn{3}{|c|}{ Experiment E4 } \\
\hline & 1991 & 1992 & 1993 & 1991 & 1992 & 1993 \\
\hline GNP & -0.6 & -0.2 & -0.2 & 0.0 & 0.5 & 1.0 \\
\hline Foreign deficit & 3.0 & 1.6 & 1.8 & 4.3 & 2.7 & 3.2 \\
\hline Public disposable income & -11.6 & -6.5 & -7.5 & -11.6 & -6.6 & -7.9 \\
\hline Private disposable income & 1.0 & 0.6 & 0.6 & 1.6 & 1.4 & 2.0 \\
\hline \multicolumn{7}{|l|}{ Consumption Expenditures } \\
\hline Public & -12.0 & -6.0 & -5.7 & -12.0 & -6.0 & -5.7 \\
\hline Private & 1.0 & 0.6 & 0.6 & 1.6 & 1.4 & 2.0 \\
\hline \multicolumn{7}{|l|}{ Domestic Savings } \\
\hline Public & -0.6 & -0.2 & -0.2 & -0.1 & 0.4 & 1.0 \\
\hline Private & 1.0 & 0.6 & 0.5 & 1.6 & 1.4 & 2.0 \\
\hline \multicolumn{7}{|l|}{ Investment Expenditures } \\
\hline Public & 1.0 & 1.0 & 1.0 & 1.0 & 1.0 & 1.0 \\
\hline Private & 1.9 & 1.0 & 1.2 & 2.9 & 2.1 & 3.1 \\
\hline Exports & 1.2 & 0.6 & 0.7 & 3.8 & 3.6 & 5.5 \\
\hline Imports & 0.8 & 0.5 & 0.4 & 2.1 & 2.0 & 2.7 \\
\hline \multicolumn{7}{|l|}{ Private Factor Incomes } \\
\hline Rural & 3.0 & 1.6 & 1.6 & 4.8 & 3.9 & 5.6 \\
\hline Marginal labour & 0.2 & 0.2 & 0.1 & 0.7 & 0.8 & 1.4 \\
\hline Wage-labour & -5.9 & -3.0 & -2.8 & -6.4 & -3.5 & -3.3 \\
\hline Industrial labour & -1.2 & -0.4 & -0.3 & -3.8 & -3.3 & -3.8 \\
\hline Services labour & -8.4 & -4.3 & -4.3 & -7.8 & -3.6 & -3.1 \\
\hline Industrial capital & 0.5 & 0.4 & 0.5 & -1.2 & -1.2 & -2.0 \\
\hline Services capital & 0.7 & 0.3 & 0.2 & 1.7 & 1.4 & 2.4 \\
\hline
\end{tabular}




\section{Summary and Conclusions}

In this study I have investigated the post-1990 evolution of the Turkish economy within a structuralist macro-economic model, which is utilised as a 'social laboratory' to analyse a series of 'counter-factual' policy environments so as to disintegrate the underlying mechanisms behind the 1994 crisis.

The counter-factual policy simulations of the model reveal the importance of the public sector fiscal deficits as a major factor generating inflationary dynamics in the Turkish economy. However, the model solutions also underscore the crucial function of the state in sustaining and re-distributing capitalist incomes in response to the intensified conflicting claims on national income through the $1990 \mathrm{~s}$. At the micro level, the state is observed to interfere with the domestic commodity markets through an extensive scheme of production subsides and current transfers, and through effective price controls on the state enterprises which strategically produce mostly intermediate inputs in an attempt to generate cost-savings to the private capital. Through this process, conducive conditions could have been generated for the private capital to 'absorb' the rapid increases in labour costs of the late 1980s.

The role of foreign capital inflows was the second issue analysed with the aid of the model. With full capital account liberalisation in 1989, Turkey received significant foreign inflows of short term capital, which were attracted by the arbitrage differential between high domestic real interest rates and the appreciated foreign exchange rate. Under the experiment, this process was reversed and the foreign borrowing was set to zero in net terms. It was found that the foreign capital inflows served to postpone the evolving economic crisis by providing timely financial resources to the public sector to (partially) cover its growing deficits. Furthermore, by stimulating the private consumption demand, they generated short term growth sparks for the economy. Yet the fragile balance upon which this mechanism rested was clearly not sustainable, and its collapse at the end of 1993 meant a severe contraction in real output and financial chaos.

The experiment, which analyses the effects of real wage increases on price inflation, reveals that, by keeping the real wages at their 1990 level, the reduction in the inflation rate can be expected to lie between $4 \%$ and $8 \%$. This would depend on whether wage reductions will have direct cost savings on public expenditures. However, these abstract results of the experiment do not take account of the pressures emanating from the oligopolistic pricing behaviour prevalent in the manufacturing industry. In this regard, the simulation results reveal that the mark-up based oligopolistic pricing strategies in manufacturing have both inflationary and contractionary consequences for the domestic economy.

In conclusion, based on the political economy perspective of class conflict and political pressure, the current model underscores the fact that conflicting claims of various social classes on national output have to be regarded as important sources of disequilibria in the domestic economy; and that the erosion of fiscal balances of the public sector is but a mere reflection of the state's intervention in the factor and the product markets in an attempt to resolve the distributional conflict in favour of capital, during a period of real wage increases and faltering production and trade performance.

\section{Notes}

A previous version of the paper (Economic Development Center Bulletin No. 95-2) was drafted when the author was visiting the Department of Applied Economics of The University of Minnesota, St Paul, 
USA, for which gencrous hospitality is gratefully acknowledged. Research support was initiated by a project grant from Harb-Is (Union for Defense Industry Workers of Turkey). I further wish to acknowledge my indebtedncss to Korkut Boratav, Merih Celasun, Erol Balkan, Ahmet Oncü, Sherman Robinson, Terry Roe, Xinshen Diao, Oktar Türel, Tuncer Bulutay, Bilsay Kuruç, Faruk Selçuk, Ahmet Köse, Ahmet Tiktik, members of the Harb-Is Research Department, and to an anonymous referee of this Journal for their invaluable comments and suggestions. Needless to say, none of them bears any responsibility for the possible errors and/or omissions of the propositions that the paper claim.

1. The full algebraic system of equations of the model are given in Yeldan (1995) 'Political economy perspectives on the 1994 Turkish economic crisis: a CGE modeling analysis'. University of Minnesota, Economic Development Center Bulletin, No. 95-1.

2. Note that given the endogenous specification of the price level, one can exogenously parameterise only the nominal values of such macro aggregates. Based on the model's simulation results, it can be calculated that this amounts to an average real increase of approximately $10 \%$ over the historically realised path.

3. Experiment E3 effectively distinguishes aggregate public consumption (GDTOT) into two categories: wage costs of public employees ( $W_{\text {PUB }}{ }^{\star} L_{P U 1}$ ), and non-labour public expenditures (GDNONPER). Here, the model continues to regard GDNONPER as exogenously given in real 1990 prices. Experiment E3, reduces the rate of increase of real $W_{\text {PUB }}$ to zero, and, by fixing the aggregate employment of public employees, Lrus, achieves savings in the public wage bill. If, per contra, $L_{\text {PUB }}$ were continued to be regarded as an endogenous entity, declining wage rates would have expanded employment at the public sector, without any significant savings in total wage costs.

\section{References}

Atiyas, I. (1995) Uneven governance and fiscal failure: the adjustment expcrience of Turkey, in: $L$. Frischtak \& I. Atiyas (Eds) Governance, Leadership, and Communication: building constitutiences for economic reform, (Washington DC, The World Bank).

Balkan, E. \& Yeldan, E. (1996) Financial liberalization in developing countries: the Turkish experience. Forthcoming in Medhora \& Fanelli (Eds) Financial Liberalization in Developing Countries, (Macmillan Press).

Boratav, K., Turel, O. \& Yeldan, E. (1994) Distributional dynamics in Turkey under 'structural adjustment' of the 1980's, New Perspectives on Turkey, 11, pp. 43-71.

Boratav, K., Turel, O. \& Yeldan, E. (1996) Dilemmas of structural adjustment and environmental policies under unstability: post-1990 Turkcy, World Development, 24, pp. 373-393.

Bourguignon, F., de Melo, J. \& Suwa, A. (1991) Modeling the effects of adjustment on income distribution, World Development, 13(1,2), pp. 29-64.

Davies, R. \& Rattso, J. (1996) Growth, distribution and environment: macroeconomic issues in Zimbabwe, World Development, 24, pp. 395-405.

Dervis, K., de Melo, J. \& Robinson, S. (1982) General Equilibrium Models for Development Policy, (London, Cambridge University Press).

Gibson, B. \& van Seventer, D. (1996) A tale of two models: comparing structuralist and neoclassical computable general equilibrium models for South Africa, University of Vermont, mimeo.

Istanbul Chamber of Industry (1995) 500 Largest Industrial Enterprises, Istanbul.

Kose, A. \& Yeldan, E. (1996) Cok Sektorlu Hesaplanabilir Genel Denge Modellerinin Veri Tabani Uzerine Notlar: Turkiye 1990 Sosyal Muhasabe Matrisi, METU Studies in Development, 23(1), pp. 59-83.

Onder, I., Turel, O. Ekinci, N. \& Somel, C. (1993) Turkiye 'de Kamu Maliyesi, Finansal Yapi ve Politikalar, (Istanbul, Tarih Vakfi Yurt Yay).

Sak, G., Ozatay, F. \& Ozturk, E. (1996) 1980 Sonrasinda Kaynaklarin Kamu ve Ozel Sektor Arasinda Paylasimi, Istanbul: TUSIAD, No. 96-1/189.

State Institute of Statistics (SIS) Annual Statistical Survey, various years, Ankara.

State Institute of Statistics (SIS) Manufacturing Industry Surveys, Ankara.

State Institute of Statistics (SIS) (1994) The Input-Output Structure of the Turkish Economy, 1990, Ankara.

Taylor, L. (1981) Structuralist Macroeconomics, (New York, Basic Books).

Taylor, L. (1991) Socially Relevant Policy Analysis: Structuralist CGE Models for the Developing World, (Massachusetts, MIT Press).

Taylor, L. (1994) Gap models, foumal of Development Economics, 45, pp. 17-34.

Taylor, L. (1995) Sustainable development: an introduction, World Development, 24, pp. 215-225. 
Uygur, E. (1994) Turkiye'de Ekonomik Kriz: Olusumu, Seyri ve Gelecegi, Iktisat, Isletme ve Finans, 9(100), pp. 42-54.

Yeldan, E. (1995) Surplus creation and extraction under structural adjustment: Turkey, 1980-1992, Review of Radical Political Economics, 27(2), pp. 38-72. 